\title{
What Determines the Financial and Insurance Services Exports: The Case of the United Kingdom
}

\author{
Emmanouil Karakostas \\ Ph.D., Dept. of International and European Studies, School of Economics, Business and \\ International Studies, University of Piraeus, Piraeus, Greece
}

\begin{abstract}
The financial sector is a very basic pillar of the international financial system. Almost all countries of the present international economic system participate in international financial services. Today's era, due to intense globalization, constant capital movements, continuous commercial integration and the ever-increasing financial interconnection, have made financial and insurance services an essential element of the present reality. The financial sector is an industry that is very 'sensitive' to the macroeconomic and political stability of countries. This means that countries that are considered unstable cannot have a positive impact on their financial activities. One country that has a strong position in the financial sector is the United Kingdom (UK). The question that can be asked is this: what are the factors that determine the optimal functioning of financial and insurance activities. One answer could be the strong financial institutions of a country. Another answer is the corruption indicator. Or even the existence of intervention by the state apparatus in the financial functions. Of course, these factors must have tangible proof of the functioning of the economy. State intervention, for example, does not entirely mean that it is dysfunctional. This study will seek to create a framework for the analysis of financial services factors. The methodology applied is The Multiple Linear Regression - Ordinary Least Squares (OLS).
\end{abstract}

Keywords: Financial - Insurance Services, Exports, OLS.

\section{Introduction}

Financial services are essential in modern times. Essentially it can be said that they are the basis on which the modern global economic system has been built. Financial and Insurance services make up the largest proportion of tradable services according to Rickards (2019). Moreover, he says that the opening up of financial sectors to international competition, the outsourcing of certain financial services and the growth of internationally active banks are some of the reasons that have led to a rise in Financial and Insurance Services. Continuing, he says that the countries that have a strong presence in the Financial and Insurance Services are Singapore, Switzerland, the United Kingdom, the United States and the Euro Area. He also mentions that the United Kingdom is one of the largest exporters of financial services and that 
the United Kingdom is the largest foreign exchange market in the world and provides the most cross-border bank lending.

It is interesting to present some economic data ${ }^{1}$ regarding the UK economy. Figure 1. shows the Exports Of Goods and Services (\% of GDP) and the Real Effective Exchange Rate (REER) $(2010=100)$ of the United Kingdom for the period 1990-2020. Figure 2. shows the Inflation (annual \%) and the GDP Growth (annual \%) of the United Kingdom for the period 1990-2020.

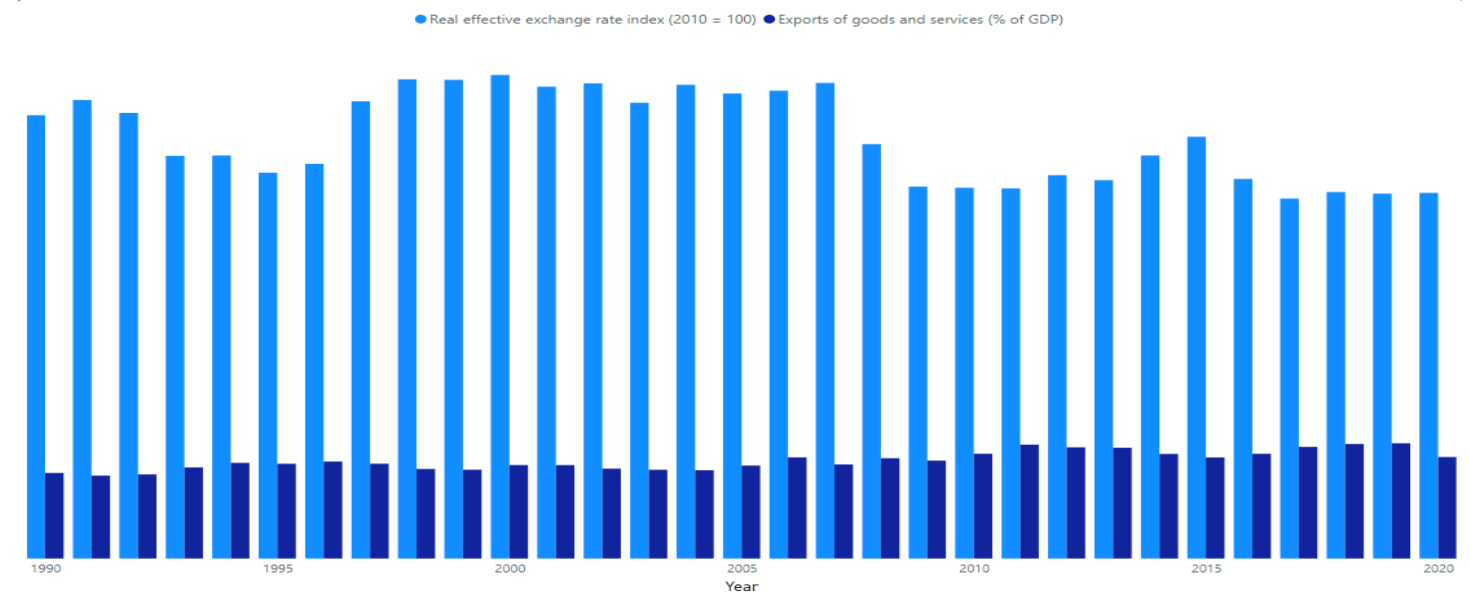

Figure 1. The Exports of Goods and Services (\% of GDP) and the Real Effective Exchange Rate $(2010=100)$ of United Kingdom for the period 1990-2020 (World Bank, 2021).

The average of exports of goods and services is 26.43 and the variation is 6.24 . The average of Real Effective Exchange Rate is the value of 113.69 and the variance is 139.39. While the proportion of UK exports does not fluctuate in a large proportion, the trade competitiveness has high variation.

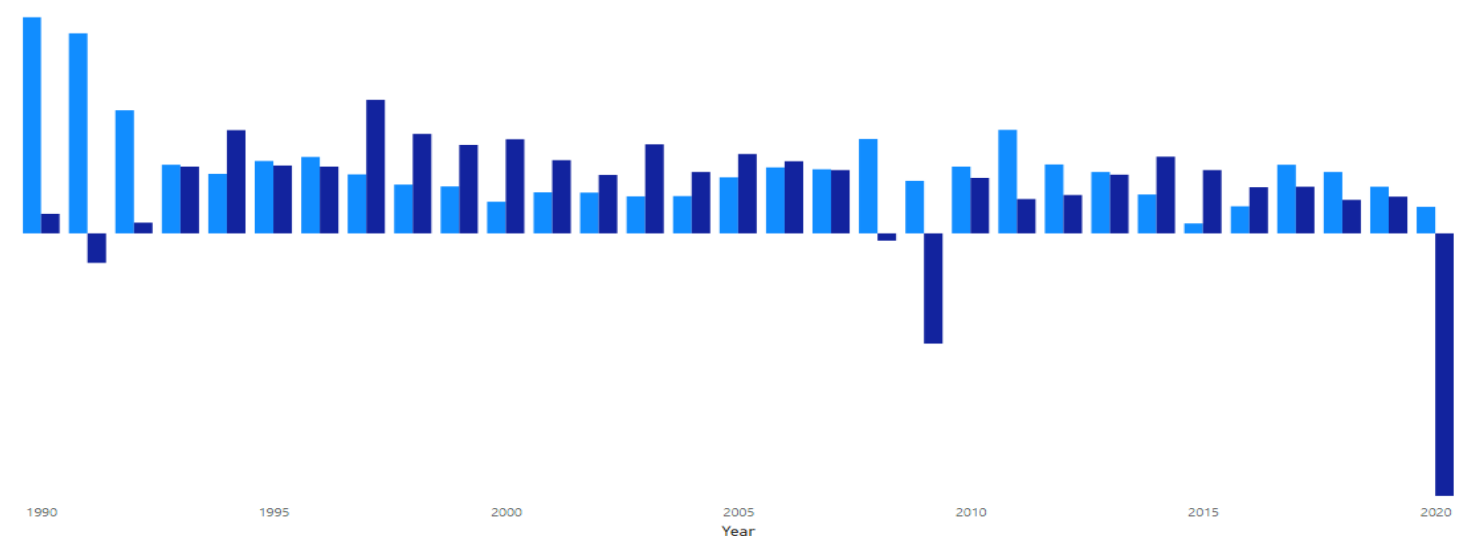

Figure 2. The Inflation (annual \%) and the GDP Growth (annual \%) of United Kingdom for the period 1990-2020 (World Bank, 2021).

\footnotetext{
${ }^{1}$ See Appendix.
} 
The average of GDP Growth is 1.60 and the variation is 7.00. The average of Inflation is the value of 2.49 and the variance is 2.63 . It is observed that both the inflation rate and the GDP Growth have a high variation for the period. The important thing to see is whether the fluctuations in the UK economy have an impact on financial and insurance services.

Financial and insurance services may be characterized by a high sensitivity to economic disruptions (Feyen et al., (2011); Beck and Webb (2003); Boyed and Champ (2003); Boyd et al., (2001)). It is therefore necessary to investigate the factors that determine the exports of financial and insurance services.

The purpose of this study is to clarify the determinants of the financial and insurance services exports of United Kingdom. The remainder of this paper is structured as follows: in the second part, the review of the literature is cited. In the third part of this paper the methodology is cited. In the fourth part the results of the regression are cited. The last part concludes. This research was based on the Linear Regression Analysis - Ordinary Least Squares (OLS). The next section presents a brief reference to the literature.

\section{Review of the Literature}

Financial services are a key element of the modern economy. A brief review of the literature is interesting. Zahler et al., (2014) mention that financial and insurance services are the most innovative sector. Moreover, Love and Mansury (2009) say that financial and insurance services engage in exporting. Briggs (2017) refer the importance of innovation in the financial and insurance services. King and Levine (1993a, 1993b); Rousseau and Wachtel (1998); Levine and Zervos (1998) and, Fink et al., (2003) mention the link between finance and growth. Catalan et al, (2000); Ward and Zurbruegg, (2000); Beenstock et al, (1988); Browne and Kim, (1993); Browne et al., (2000); Das et al., (2003); Holsboer, (1999) investigate the link between insurance and growth. Researchers such as Deaton (1992); Muradoglu and Taskin, (1996); Jabbar et al., (2002); Pal (2002); Barslund and Tarp (2008) and, Bendig et al., (2009) mention the financial and insurance services in developing countries. Researches such as Merton, (1992); McKinnon, (1973); Shaw, (1973); Jensen and Murphy, (1990); King and Levine, (1993); Obstfeld, (1994); Bencivenga et al., (1996); (Hicks, (1969); North, (1981); Greenwood and Jovanovic, (1990) mention the importance and role of the financial sector in the economy. Researches such as Grossman and Hart, (1980); DeAngelo and Rice, (1983); Stiglitz, (1985); Bhide, (1993); Jensen, (1993); Allen and Gale, (1997), (2000); Chakraborty and Ray, (2004); Levine, (2005) investigate the relationship of the financial sector with the banking industry. Researches such as Spiro, (1990); Mok, (1993); Shiller, (1988); Asprem, (1989); Barsky, (1989) mention the role of interest rates. Still, studies such as Ross, (1976); Adler and Dumas, (1983); Jorion, (1991); Dornbusch and Fisher (1980) investigate the effect of the exchange rate. Researches such as Hausmann and Fernández-Arias, (2000a), (2000b); Claessens et al., (2001) mention the role of foreign direct investment. Researches such as Calderon et al., (2002); Frankel and Rose (1998); Otto et al., (2001); Bordo and Helbling (2003); Kose et al., (2003); Imbs (2004); Eichengreen et al., (1996); Glick and Rose (1999); and Chinn and Forbes (2004) mention the role of trade. Surveys such as Amtiran, et al., (2017); Bulmash \& Trivoli (1991); Maysami \& Koh (2000); Simpson \& Evans (2003); Brahmasrene \& Jiranyakul (2007); Liu \& Shrestha (2008); Ali (2011); Kuwornu \& Victor (2011); Murcia (2014); Kotha \& Sahu (2016) and Asekome \& Agbonkhese (2015) have investigated the role of macroeconomic variables. The next section shows the methodology and the data. 


\section{Methodology and Data}

This study attempts to investigate the factors that determine the financial and insurance services exports of United Kingdom. This research uses the percentage of exports of Financial and Insurance Services Exports. The period under review is 1993-2019. The trading partners selected are Germany, France, Ireland, Netherlands and United States (WITS, 2021). The countries have been selected because for most of the period under review they are among the top five export destinations for the period under review.

The database for this study is OECD and World Bank. The time period and the examining country has chosen firstly and mostly due to the availability of data. Moreover, the time period has chosen due to the fact that covers a sufficient time frame.

This study uses multiple-regression model as an estimator of annual time series data. The dependent variable is exports of Financial and Insurance Services. The study model expresses the exports of financial and insurance services as a function of: firstly, the Inflation of United Kingdom, the Exchange Rate of United Kingdom, the Multifactor Productivity of United Kingdom, the Industrial Production of Germany, France, Ireland, Netherlands and United States and the Investment (GFCF) of Germany, France, Ireland, Netherlands and United States. The above are the independent variables.

The study uses the traditional Multiple Regression technique, especially the traditional Ordinary Least Squared (OLS) technique (Hutcheson, 2011). Table 1. shows the dependent variable and the explanatory variables of the model.

Table 1: The dependent variable and the explanatory variables of the model.

\begin{tabular}{|c|c|c|c|c|c|c|c|c|c|c|c|c|c|c|}
\hline Year & $\begin{array}{l}\text { Financial and } \\
\text { Insurance } \\
\text { Exports (\% of } \\
\text { BoP) United } \\
\text { Kingdom }\end{array}$ & $\begin{array}{l}\text { Inflation, GDP } \\
\text { deflator } \\
\text { (annual \%) } \\
\text { United } \\
\text { Kingdom* }\end{array}$ & $\begin{array}{c}\text { Exchange rates } \\
\text { Total, National } \\
\text { currency units/US } \\
\text { dollar - United } \\
\text { Kingdom }{ }^{*}\end{array}$ & $\begin{array}{c}\text { Multifactor } \\
\text { Productivity } \\
\text { (annual \%) } \\
\text { United } \\
\text { Kingdom }^{* *}\end{array}$ & $\begin{array}{c}\text { Industrial } \\
\text { Production } \\
\text { Total, France } \\
\text { (Index } \\
2015=100)^{* * * * *}\end{array}$ & $\begin{array}{c}\text { Industrial } \\
\text { Production } \\
\text { Total, Germany } \\
\text { (Index } \\
2015=100)^{* * *}\end{array}$ & $\begin{array}{c}\text { Industrial } \\
\text { Production } \\
\text { Total, Ireland } \\
\text { (Index } \\
2015=100)^{* *}\end{array}$ & $\begin{array}{l}\text { Industrial } \\
\text { Production } \\
\text { Netherlands } \\
\text { Total, (Index } \\
2015=100)^{* *}\end{array}$ & $\begin{array}{c}\text { Industrial } \\
\text { Production } \\
\text { United States } \\
\text { Total, (Index } \\
2015=100)^{* * *}\end{array}$ & $\begin{array}{c}\text { Investment } \\
\text { (GFCF) Total, } \\
\text { Annual growth } \\
\text { rate (\%) } \\
\text { France } * *\end{array}$ & $\begin{array}{c}\text { Investment } \\
\text { (GFCF) Total, } \\
\text { Annual growth } \\
\text { rate (\%) } \\
\text { Germany** }\end{array}$ & $\begin{array}{c}\text { Investment } \\
\text { (GFCF) Total, } \\
\text { Annual growth } \\
\text { rate (\%) } \\
\text { Netherlands** }\end{array}$ & $\begin{array}{c}\text { Investment } \\
\text { (GFCF) Total, } \\
\text { Annual growth } \\
\text { rate (\%) } \\
\text { Ireland }{ }^{* * *}\end{array}$ & $\begin{array}{l}\text { Investment } \\
\text { (GFCF) Total, } \\
\text { Annual growth } \\
\text { rate (\%) United } \\
\text { States } * *\end{array}$ \\
\hline 1993 & 16.12 & 2.73 & 0.667 & 2,00 & \begin{tabular}{|l|}
86.8 \\
\end{tabular} & 67.1 & 16.1 & 78.9 & 65,00 & -5.4 & -4.5 & -1.6 & -5.1 & \begin{tabular}{|l|} 
\\
\end{tabular} \\
\hline 1994 & 16.79 & 1.39 & 0.653 & 1.4 & 90.0 & 69.2 & 18 & 82.7 & 68.4 & 1.6 & 3.6 & 2 & 11.8 & 6.1 \\
\hline 1995 & 17.03 & 11.27 & 0.634 & 0.1 & 92.7 & 69.8 & 21.5 & 85.1 & 71.6 & 1.3 & -0.2 & 5.9 & 15.8 & 5.2 \\
\hline 1996 & 18.76 & 4.12 & 0.641 & 0.7 & 93.5 & 69.4 & 23.2 & 87.2 & 74.8 & 0.8 & -0.4 & 6.7 & 16.4 & 7.7 \\
\hline 1997 & 21.73 & -0.07 & 0.611 & 4.3 & 97.5 & 71.8 & 27.3 & 86.7 & 80.2 & 0.8 & 0.5 & 6.4 & 15.8 & 7.2 \\
\hline 1998 & 19.72 & 1.03 & 0.604 & 1.8 & 101.6 & 75.0 & 32.7 & 88.4 & 84.9 & 6.4 & 4.0 & 6.8 & 13.4 & 9.3 \\
\hline 1999 & 22.92 & 0.94 & 0.618 & 2.1 & 104.3 & 76.2 & 37.5 & 91 & 88.6 & 7.8 & 4.3 & 10 & 14.1 & 8.3 \\
\hline 2000 & 23.43 & 1.83 & 0.661 & 2.4 & 108.6 & 80.4 & 42.9 & 95.9 & 92.1 & 6.6 & 2.1 & 2.3 & 5.1 & 6.4 \\
\hline 2001 & 25.73 & 1.12 & 0.695 & 1.4 & 109.9 & 80.5 & 47.6 & 95.9 & 89.2 & 2.3 & -2.6 & 1.3 & 5.8 & -0.4 \\
\hline 2002 & 25.43 & 2.11 & 0.667 & 1.7 & 108.6 & 79.5 & 51.5 & 97 & 89.4 & -0.9 & -6.1 & -4.1 & 5.6 & -1.7 \\
\hline 2003 & 27.80 & 2.37 & 0.612 & 2.5 & 107.7 & 79.7 & 54.4 & 95.8 & 90.6 & 1.9 & -1.6 & -1.7 & 8 & 4.2 \\
\hline 2004 & 27.23 & 2.53 & 0.546 & 1.6 & 110.1 & 83.1 & 55.1 & 99.9 & 93.0 & 3.5 & -0.4 & 0.2 & 9.8 & 6.0 \\
\hline 2005 & 30.65 & 2.70 & 0.55 & 0.6 & 110.0 & 85.9 & 57.2 & 100.2 & 96.1 & 2.9 & 0.9 & 3.3 & 16.8 & 6.1 \\
\hline 2006 & 32.76 & 2.81 & 0.543 & 1.5 & 110.8 & 90.9 & 59 & 102.3 & 98.2 & 3.6 & 7.5 & 7 & 7.2 & 2.7 \\
\hline 2007 & 35.25 & 2.70 & 0.5 & 1,00 & 112.0 & 96.9 & 62.1 & 106.5 & 100.8 & 5.5 & 3.6 & 14.8 & 0 & -0.6 \\
\hline 2008 & 34.29 & 3.08 & 0.544 & -0.5 & 109.0 & 97.7 & 60.7 & 107.3 & 97.3 & 0.9 & 1.6 & -3 & -11.6 & -4.2 \\
\hline 2009 & 34.85 & 1.62 & 0.642 & -3.2 & 95.4 & 80.8 & 58 & 99.4 & 86.1 & -9.1 & -9.5 & -8.6 & -16.9 & -12.5 \\
\hline 2010 & 32.83 & 1.62 & 0.647 & 1.8 & 99.9 & 90.4 & 63 & 106.9 & 90.9 & 2.1 & 5.3 & -6.8 & -15 & 2.2 \\
\hline 2011 & 34.25 & 2.07 & 0.624 & -0.3 & 102.4 & 98.1 & 62.7 & 106.4 & 93.7 & 2.1 & 7.4 & 4.9 & -0.1 & 4.6 \\
\hline 2012 & 32.38 & 1.66 & 0.633 & -0.7 & 99.8 & 97.1 & 61.8 & 105.9 & 96.5 & 0.2 & -0.2 & -6.3 & 16.1 & 6.9 \\
\hline 2013 & 32.33 & 1.78 & 0.64 & 0.3 & 99.5 & 97.0 & 60.4 & 106.5 & 98.5 & -0.8 & -1.3 & -1.6 & -4.1 & 3.6 \\
\hline 2014 & 30.59 & 1.73 & 0.608 & 0.1 & 98.4 & 99.0 & 73 & 103.6 & 101.4 & 0.0 & 3.2 & -2.4 & 18.5 & 5.1 \\
\hline 2015 & 28.60 & 0.66 & 0.655 & 1.2 & 100.0 & 100.0 & 100 & 100 & 100.0 & 1.0 & 1.7 & 29 & 50.6 & 3.7 \\
\hline 2016 & 28.34 & 2.15 & 0.741 & -0.7 & 100.5 & 101.5 & 101.8 & 101.4 & 97.8 & 2.7 & 3.8 & -7.3 & 50.2 & 2.1 \\
\hline 2017 & 26.99 & 1.94 & 0.777 & 0.5 & 102.5 & 104.5 & 99.5 & 102.5 & 99.1 & 4.7 & 2.6 & 4.2 & -0.6 & 3.8 \\
\hline 2018 & 26.47 & 2.25 & 0.75 & 0,00 & 103.2 & 105.7 & 94.6 & 103.1 & 102.3 & 3.3 & 3.4 & 3.6 & -8.9 & 4.4 \\
\hline 2019 & 25.29 & 2.15 & 0.783 & -0.3 & 103.6 & 101.2 & 97.3 & 102.4 & 101.4 & 4.0 & 1.8 & 6.2 & 99.5 & 3.1 \\
\hline
\end{tabular}

Source: (World Bank, (2021)* OECD $\left.(2021)^{* * *}\right)$.

The study sets up the estimated multiple-regression model to test the above -mentioned hypotheses as follows:

FISExpUK $_{i t}=\beta_{o}+\beta_{1}$ InfUK $_{t}+\beta_{2}$ ExcRatUK $_{t}+\beta_{3}$ MulPrUK $_{t}+\beta_{4} I n d$ ProFr $_{t}+$ $\beta_{5}$ IndProGer $_{t}+\beta_{6}$ IndProIr $_{t}+\beta_{7}$ IndProNeth $_{t}+\beta_{8}$ IndProUnSt $_{t}+\beta_{9}$ InvestFr $_{t}+\beta_{10}$ InvestGer $_{t}+$ $\beta_{11}$ InvestNeth $_{t}+\beta_{12}$ InvestIr $_{t}+\beta_{13}$ InvestUnSt $_{t}+e_{t}$ 
Where:

FISExpUK $K_{t}$ : stands for Financial and Insurance Exports (\% of BoP) - United Kingdom $\beta_{0}$ : stands for the constant amount or the intercept.

$\beta_{1}-\beta_{13}$ : are coefficients of the explanatory variables.

InfUK $K_{t}$ : Inflation, GDP deflator (annual \%) United Kingdom

ExcRatUK $_{t}$ : Exchange rates Total, National currency units/US dollar - United Kingdom

$M u l P r U K_{t}$ : Multifactor Productivity (annual \%) - United Kingdom

IndProFr $_{t}$ : Industrial Production Total, France (Index 2015=100)

IndProGer: Industrial Production Total, Germany (Index 2015=100)

IndProIr $r_{t}$ Industrial Production Total, Ireland (Index 2015=100)

IndProNeth : Industrial Production Total, Netherlands (Index 2015=100)

IndProUnSt $t_{t}$ Industrial Production Total, United States (Index 2015=100)

InvestFr $r_{t}$ : Investment (GFCF) Total, Annual growth rate (\%) France

InvestGer $:$ Investment (GFCF) Total, Annual growth rate (\%) Germany

InvestNeth: Investment (GFCF) Total, Annual growth rate (\%) Netherlands

InvestIr $r_{t}$ : Investment (GFCF) Total, Annual growth rate (\%) Ireland

InvestUnSt $t_{t}$ Investment (GFCF) Total, Annual growth rate (\%) United States

$e$ : stands for the error term.

$t$ : stands for the year from the period 1993-2019.

$i$ : stands for the country.

The next section presents the results of linear regression.

\section{Results}

Table 2. shows the regression results.

Table 2: Regression results

\begin{tabular}{|c|c|}
\hline & Dependent variable: \\
\hline & FISExpUK $_{\mathrm{t}}$ \\
\hline $\operatorname{InfU} K_{t}$ & $-0.315^{*}(-0.651,0.021)$ \\
\hline ExcRatUK $_{t}$ & $-18.724 * *(-34.252,-3.197)$ \\
\hline MulPrUK & $-0.371(-1.063,0.321)$ \\
\hline IndProFr $r_{t}$ & $0.062(-0.183,0.307)$ \\
\hline IndProGer $_{t}$ & $-0.154(-0.381,0.074)$ \\
\hline IndProIr $_{t}$ & $0.040(-0.046,0.126)$ \\
\hline IndProNeth $_{t}$ & $0.646 * * *(0.383,0.908)$ \\
\hline IndProUnSt $t_{t}$ & $0.004(-0.285,0.292)$ \\
\hline InvestFr $r_{t}$ & $-0.468 *(-0.952,0.016)$ \\
\hline InvestGer $_{t}$ & $0.275(-0.058,0.607)$ \\
\hline InvestNeth & $0.045(-0.055,0.145)$ \\
\hline InvestIr $t_{t}$ & $-0.008(-0.039,0.024)$ \\
\hline InvestUnSt $t_{t}$ & $-0.149(-0.394,0.097)$ \\
\hline$e$ & $0.424(-0.166,1.014)$ \\
\hline Constant & $-17.665(-45.600,10.269)$ \\
\hline Observations & 27 \\
\hline & 0.976 \\
\hline Adjusted $\mathrm{R}^{2}$ & 0.948 \\
\hline Residual Std. Error & $1.341(\mathrm{df}=12)$ \\
\hline F Statistic & $34.839 * * *(\mathrm{df}=14 ; 12)$ \\
\hline
\end{tabular}

Source: (Author's calculation)

The results of linear regression prove the functionality of the above model. The conclusions of this study are presented in the next section. 


\section{Conclusion}

The present study has examined the determinants of Financial and Insurance Services exports of United Kingdom. Adjusted $\mathrm{R}^{2}$ is high, with value of 0.948 . This means that the model constructed in this study explains the relationship of independent variables to the dependent one. Basically, the bigger the Adjusted $\mathrm{R}^{2}$ the better the model fits to the data. The variables InfUK $_{t}$, ExcRatUK $_{t}$, MulPrUK $_{t}$, IndProGer $r_{t}$, InvestFr ${ }_{t}$, InvestIr ${ }_{t}$, InvestUnSt $t_{t}$ have a negative effect on the Financial and Insurance Services exports whereas the others variables have a positive effect.

Financial and Insurance Services is a branch of services which, from the results of the model of the present study, appears to be heavily influenced by the currency of the country concerned and by the production and investment of the trading partners. As can be seen from the analysis of the present research effort, it can be said that financial and insurance services (in this case the UK) are vulnerable to both inflation and the exchange rate. It can also be said that both industrial production and the investment of trading partners are important for financial and insurance services. In conclusion, the exports of financial and insurance services depend on the macroeconomic conditions of the country and on the course of production and investment of the country's trading partners. Further research is needed to establish a satisfactory analytical framework for Financial and Insurance Services.

\section{REFERENCES}

[1] Adler, M. and Dumas, B. "International portfolio choice and corporation finance: a synthesis". Journal of Finance, vol. 38, 1983, pp. 925-984.

[2] Ali, M. "Impact of Micro and Macroeconomic Variables on Emerging Stock Market Return: A Case on Dhaka Stock Exchange (DSE)”. Interdisciplinary Journal of Research in Business, vol. 1, 2011, pp. 8-16.

[3] Allen, F. and Gale, D. "Financial markets, intermediaries, and intertemporal smoothing". Journal of Political Economy, vol. 105, 1997, pp. 523-546.

[4] Allen, F. and Gale, D. "Comparing Financial Systems". MIT Press, Cambridge, MA, 2000.

[5] Amtiran, P. Y., Indiastuti, R., Nidar, S. R., and Masyita, D. "Macroeconomic Factors and Stock Returns in APT Framework". International Journal of Economics and Management, vol. 11, 2017, pp. 197-206.

[6] Asekome, M. O., and Agbonkhese, A. O. "Macroeconomic Variables, Stock Market Bubble, Meltdown, and Recovery: Evidence from Nigeria". Journal of Finance and Bank Management, vol. 3, 2015, pp. 25-34.

[7] Asprem, M. "Stock prices, asset portfolios and macroeconomic variables in ten European countries". Journal of Banking and Finance, vol. 13, 1989, pp. 589-612.

[8] Barsky, R. "Why don't the prices of stocks and bonds move together?" American Economic Review, vol. 79, 1989, pp. 1132-1145.

[9] Barslund, M. and Tarp, F. "Formal and informal rural credit in four provinces of Vietnam". Journal of Development Studies, vol. 44, 2008, pp. 485-503.

[10] Beck, T.H.L. and Webb, I. "Economic, demographic, and institutional determinants of life insurance consumption across countries". World Bank Economic Review, vol. 17, 2003, pp. 51-88.

[11] Beenstock, M., Dickinson, G. and Khajuria, S. "The Relationship between Property-Liability Insurance Penetration and Income: An International Analysis". The Journal of Risk and Insurance, vol. 55, 1988, pp. $259-272$.

[12] Bencivenga, V.R., Smith, B.D. and Starr, R.M. "Equity markets, transactions costs, and capital accumulation: an illustration". World Bank Economic Review, vol. 10, 1996, pp. 241-265. 
[13] Bendig, M., Giesbert, L. \& Steiner, S. "Savings, Credit and Insurance: Household Demand for Formal Financial Services in Rural Ghana". GIGA Working Paper Series, No. 94, 2009, Hamburg: German Institute of Global and Area Studies.

[14] Bhide, A. "The hidden costs of stock market liquidity". Journal of Financial Economics, vol. 34, 1993, pp. 1-51.

[15] Bordo, M. and Helbling, T. "Have national business cycles become more synchronized?". NBER Working Paper 10130, National Bureau of Economic Research, 2003.

[16] Boyd, J., Levine, R., and Smith, B. "The impact of inflation on financial market performance". Journal of Monetary Economics, vol. 47, 2001, pp. 221-228.

[17] Boyed, J. and Champ, B. "Inflation and financial market performance: what have we learned in the last ten years". Working Paper 03-17. Federal Reserve Bank of Cleveland, 2003. https://www.clevelandfed.org/ /media/content/newsroom $\% 20$ and\%20events/publications/wor king\%20papers/2003/wp\%200317\%20inflation\%20and\%20financial\%20pdf.pdf?la=en

[18] Brahmasrene, T., and Jiranyakul, K. "Cointegration and Causality between Stock Index and Macroeconomics Variables in an Emerging Market". Academy of Accounting and Financial Studies Journal, vol. 11, 2007, pp. 17-30.

[19] Briggs, K. “The Impact of Innovation on Financial and Insurance Services Exports". The B.E. Journal of Economic Analysis \& Policy, vol. 17, 2017, pp. 1-10.

[20] Browne, M.J. and Kim, K. “An International Analysis of Life Insurance Demand”. The Journal of Risk and Insurance, vol. 60, 1993, pp. $616-634$.

[21] Browne, M.J., Chung, J.W. and Frees, E.W. "International Property-Liability Insurance Consumption”. The Journal of Risk and Insurance, vol. 67, 2000, pp. 73-90.

[22] Bulmash, S., and Trivoli, G. "Time-lagged Interactions between Stock Prices and Selected Economic Variables”. The Journal of Portfolio Management, vol. 17, 1991, pp. 61-67.

[23] Calderon, C., Chong, A. and Stein, E. "Trade intensity and business cycle synchronization: are developing countries any different?”. Working Paper 195, Central Bank of Chile, 2002.

[24] Catalan, M., Impavido, G. and Musalem, A.R., "Contractual Savings or Stock Markets Development: Which Leads?”. Policy Research Paper Nr. 2421, World Bank, 2000.

[25] Chakraborty, S. and Ray, R. "Bank-Based Versus Market-Based Financial Systems: A GrowthTheoretic Analysis", Mimeo, University of Oregon, 2004.

[26] Chinn, M. and Forbes, K. "A decomposition of global linkages in financial markets over time”. Review of Economics and Statistics, vol. 86, 2004, pp. 705-722.

[27] Claessens, S., Demirgüç-Kunt, A. and Huizinga, H. "How does foreign entry affect domestic banking markets?” Journal of Banking \& Finance, vol. 25, 2001, pp. 891-911.

[28] Das, U.S., Davies, N. and Podpiera, R. "Insurance and Issues in Financial Soundness". IMF Working Paper 03/138, 2003.

[29] DeAngelo, H. and Rice, E. "Anti-takeover amendments and stockholder wealth". Journal of Financial Economics, vol. 11, 1983, pp. 329-360.

[30]Deaton, A. "Household Saving in LDC's: Credit Markets, Insurance, and Welfare". Scandinavian Journal of Economics, vol. 94, 1992, pp. 253-273.

[31] Dornbusch, R. and Fisher, S. "Exchange rates and the current account". American Economic Review, vol. 70, 1980, pp. 960-971.

[32] Eichengreen, B., Rose, A. and Wyplosz, C. "Contagious currency crises". NBER Working Paper 5681, National Bureau of Economic Research, 1996.

[33] Frankel, J. and Rose, A. "The endogeneity of the optimum currency area criteria". The Economic Journal, vol. 108, 1998, pp. 1009-1025.

[34] Feyen, E., Lester, R. and Rocha, R. "What drives the development of the insurance sector? An empirical analysis based on a panel of developed and developing countries". Policy Research Working Paper Series 5572, The World Bank, 2011.

[35] Fink, G., Haiss, P. and Hristoforova, S. "Bond Markets and Economic Growth". IEF Working Paper No. 49, Research Institute for European Affairs, University for Economics and Business Administration Vienna, 2003.

[36] Glick, R. and Rose, A. "Contagion and trade: why are currency crises regional?" Journal of International Money and Finance, vol. 18, 1999, pp. 603-617. 
[37] Greenwood, J. and Jovanovic, B. "Financial development, growth, and the distribution of income". Journal of Political Economy, vol. 98, 1990, pp. 1076-1107.

[38] Grossman, S.J. \& Hart, O. "Takeover bids, the free-rider problem, and the theory of the corporation". Bell Journal of Economics, vol. 11, 1980, pp. 42-64.

[39] Hausmann, R. and Fernández-Arias, E. "Is FDI a safer form of financing?", Inter-American Development Bank Working Paper 416, Washington, DC, April, 2000a.

[40] Hausmann, R. and Fernández-Arias, E. "Foreign direct investment: good cholesterol?", InterAmerican Development Bank Working Paper 417, New Orleans, April, 2000b.

[41] Hicks, J. “A Theory of Economic History”. Clarendon Press, Oxford, 1969.

[42] Holsboer, J.H. "Repositioning of the Insurance Industry in the Financial Sector and its Economic Role". The Geneva Papers on Risk and Insurance, vol. 24/3, 1999, pp. 243-290.

[43] Hutcheson, G.D. “Ordinary Least-Squares Regression”. In: L. Moutinho and G. D. Hutcheson, The SAGE Dictionary of Quantitative Management Research. pp. 224-228, 2011.

[44] Imbs, J., "Trade, finance, specialization, and synchronization". Review of Economics and Statistics, vol. 86, 2004, pp. 723-734.

[45] Jabbar, M.A., Ehui, S.K. and von Kaufmann, R. "Supply and demand for livestock credit in Sub-Saharan Africa: Lessons for designing new credit schemes". World Development, vol. 30, 2002, pp. 1029-1042.

[46] Jensen, M. "The modern industrial revolution, exit, and the failure of internal control systems". Journal of Finance, vol. 48, 1993, pp. 831-880.

[47] Jensen, M.C. and Murphy, K.J. "Performance pay and top-management incentives". Journal of Political Economy, vol. 98, 1990, pp. 225-264.

[48] Jorion, P. "The pricing of exchange rate risk in the stock market". Journal of Financial and Quantitative Analysis, vol. 26, 1991, pp. 361-376.

[49] King, R. and Levine, R., "Finance and growth: Schumpeter might be right". Quarterly Journal of Economics, vol. 108, 1993a, pp. 717-737.

[50] King, R. and Levine, R., "Finance, entrepreneurship, and growth - theory and evidence". Journal of Monetary Economics, vol. 32, 1993b, pp. 513-542.

[51] Kose, M., Prasad, E. and Terrones, M. "How does globalization affect the synchronization of business cycles?” American Economic Review, vol. 93, 2003, pp. 57-62.

[52] Kotha, K.K., and Sahu, B. "Macroeconomic Factors and the Indian Stock Market: Exploring Long and Short Run Relationships". International Journal of Economics and Financial Issues, vol. 6, 2016, pp. 1081-1091.

[53] Kuwornu, J., and Victor, O.-N. "Analyzing the Effect of Macroeconomic Variables on Stock Market Returns: Evidence from Ghana”. Journal of Economics and International Finance, vol. 3, 2011, pp. 605-615.

[54]Levine, R. and Zervos, S., "Stock Markets, Banks and Economic Growth". American Economic Review, vol. 88, 1998, pp. 537-558.

[55] Levine, R. "Finance and growth: theory and evidence". In: Aghion, P. and Durlauf, S. (Eds), Handbook of Economic Growth, vol. 1, 1st ed., Elsevier, 2005.

[56] Liu, M. H., and Shrestha, K. "Analysis of the Long-Term Relationship between Macroeconomic Variables and the Chinese Stock Market Using Heteroskedasticity Cointegration". Managerial Finance, vol. 34, 2008, pp. 744-755.

[57] Love, J.H. and Mansury, M.S. "Exporting and Productivity in Business Services: Evidence from the United States". International Business Review, vol. 18, 2009, pp. 630-642.

[58] Mayasami, R. K., and Koh, T. S. "A Vector Error Correction Model of the Singapore Stock market”. International Review of Economics and Finance, vol. 9, 2000, pp. 79-96.

[59] McKinnon, R.I. "Money and Capital in Economic Development". Brookings Institution, Washington, DC, 1973.

[60] Merton, R.C. "Financial Innovation and Economic Performance”. Continental Bank, Journal of Applied Corporate Finance, vol. 4, 1992, pp. 12-22.

[61] Mok, H.M.K. "Causality of interest rate, exchange rate and stock prices at stock market open and close in Hong Kong”. Asia Pacific Journal of Management, vol. 10, 1993, pp. 123-143. 
[62] Muradoglu, Y. and Taskin, F. "Differences in household savings Behavior: evidence from industrial and developing countries". The Developing Economies, vol. 34, 1996, pp. 138-153,

[63] Murcia, J. B. "Macroeconomic Estimation of Selected Philippine Stock Market Indices". Southeast Asian Interdisciplinary Research Journal, vol. 2, 2014, pp. 21-30.

[64] North, D.C. "Structure and Change in Economic History". Norton, New York, NY, 1981.

[65] Obstfeld, M. "Risk taking, global diversification and growth". American Economic Review, vol. 84, 1994, pp. 1310-1329.

[66] OECD. “United Kingdom”, 2021. https://data.oecd.org/united-kingdom.htm

[67] Otto, G., Voss, G. and Willard, L. "Understanding OECD output correlations". Research Discussion Paper 05, Reserve Bank of Australia, 2001.

[68] Pal, S. "Household sectoral choice and effective demand for rural credit in India". Applied Economics, vol. 14, 2002, pp. 1743-1755.

[69] Rickards, P. “The International Trade in Services. Bulletin - March 2019”, Global Economy, $\begin{array}{llll}\text { Reserve } \quad \text { Bank } & \text { of } & \text { Australia, }\end{array}$ https://www.rba.gov.au/publications/bulletin/2019/mar/pdf/the-international-trade-inservices.pdf

[70] Ross, S. "The arbitrage theory of capital asset pricing”. Journal of Economic Theory, vol. 13, 1976, pp. 341-360.

[71] Rousseau, P.L. and Wachtel, P. "Financial Intermediation and Economic Performance: Historical Evidence from Five Industrialized Countries”. Journal of Money, Credit and Banking, vol. 30, 1998, pp. 658-678.

[72] Shaw, E.S. "Financial Deepening in Economic Developmen". Oxford University Press, New York, NY, 1973.

[73] Shiller, R.J. "Causes of changing in financial market volatility”. The Federal Reserve Bank of Kansas City, vol. 2, 1988, pp. 1-22.

[74] Simpson, J. L., and Evans, J. P. "Banking Stock Returns and Their Relationship to Interest Rates and Exchange Rates: Australian Evidence”. University of Wollongong in Dubai Working Paper, 2003, pp. 1-35.

[75] Spiro, P.S. "The impact of interest rate changes on stock prices volatility”. Journal of Portfolio Management, vol. 16, 1990, pp. 63-68.

[76] Stiglitz, J.E. "Credit markets and the control of capital”. Journal of Money, Credit, Banking, vol. 17, 1985, pp. 133-152.

[77] Ward, D. and Zurbruegg, R. "Does Insurance promote economic growth - evidence from OECD Countries". The Journal of Risk and Insurance, vol. 67, 2000, pp. 489-506.

[78] WITS “United Kingdom Product Exports to World in US\$ Thousand 1993-2019”, 2021. https://wits.worldbank.org/CountryProfile/en/Country/GBR/StartYear/1993/EndYear/2019/Tr adeFlow/Export/Indicator/XPRT-TRD-VL/Partner/WLD/Product/all-groups

[79] World Bank "United Kingdom” 2021. https://data.worldbank.org/country/GB

[80]Zahler, A., Iacovone, L. and Mattoo, A. "Trade and Innovation in Services: Evidence from a Developing Economy”. The World Economy, vol. 37, 2014, pp. 953-979. 


\section{APPENDIX}
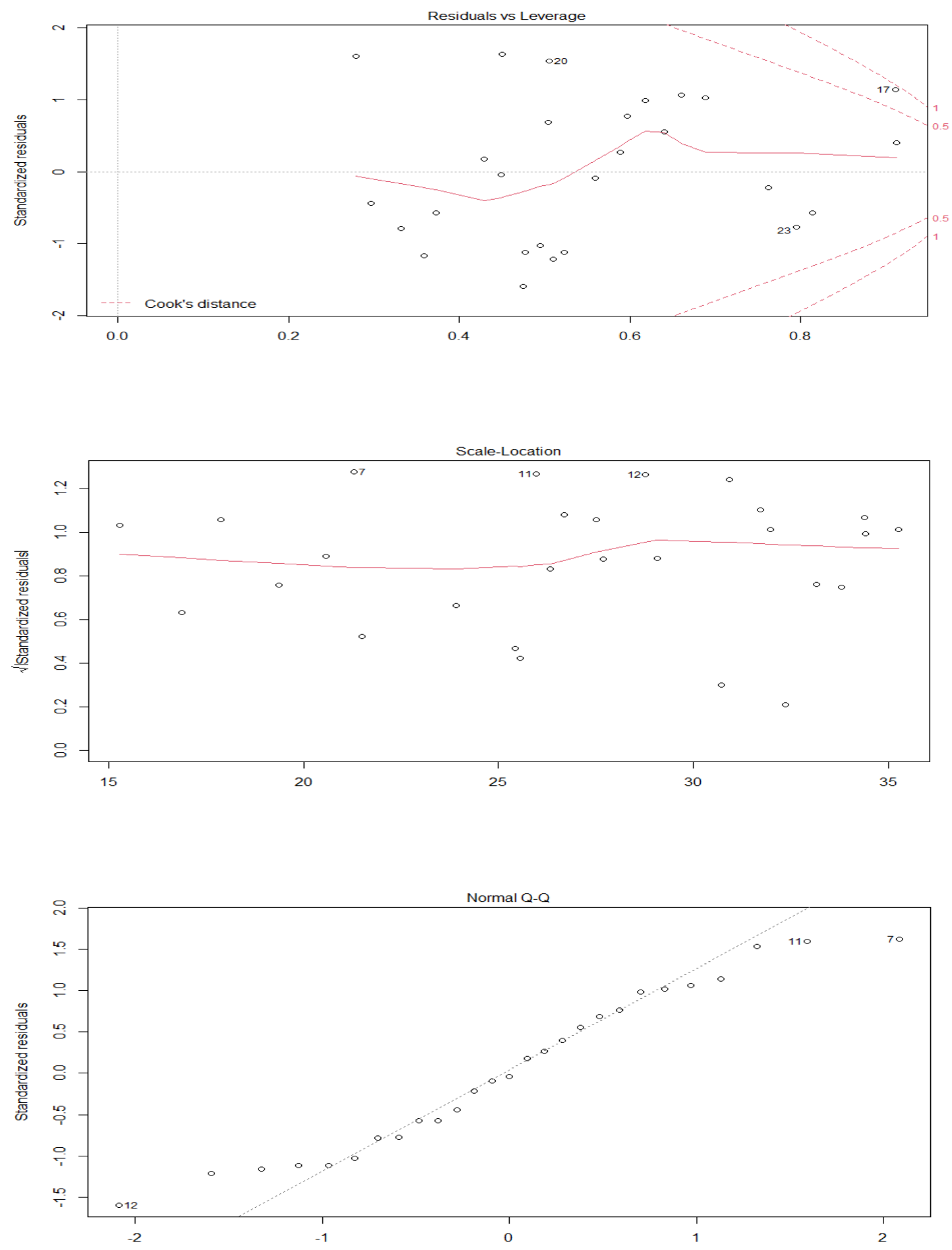


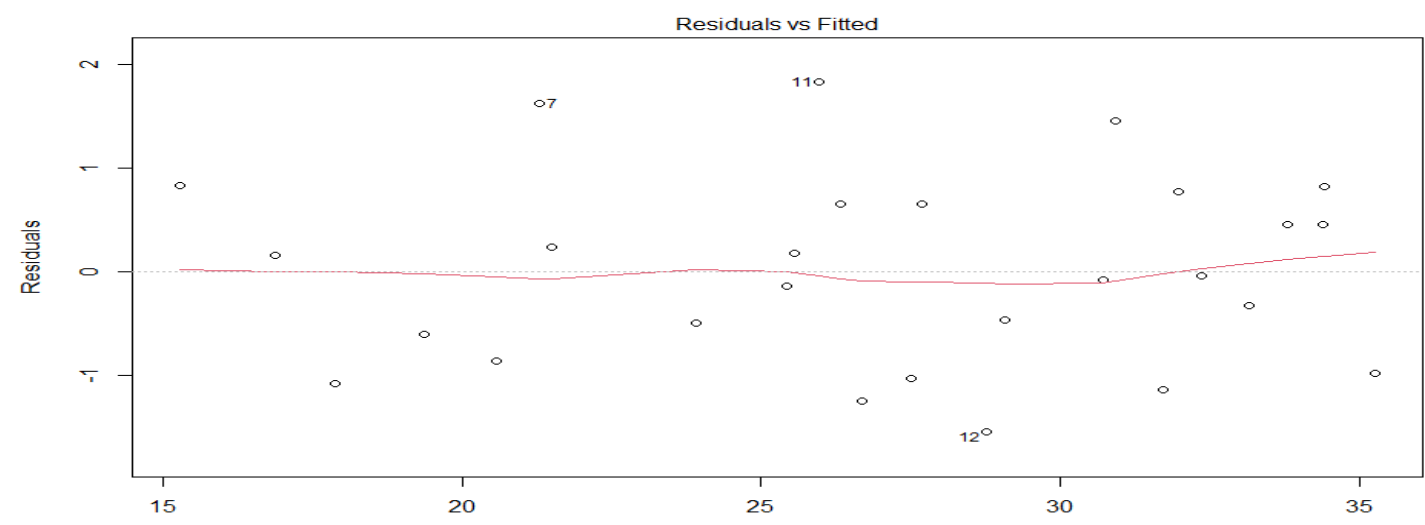

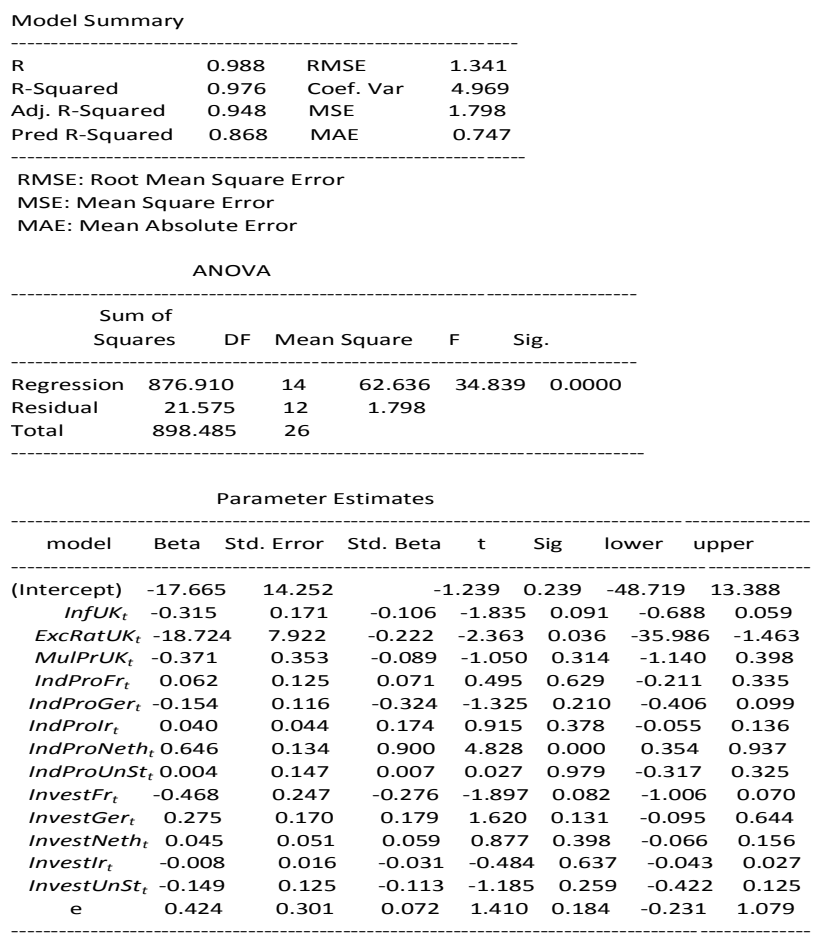

\begin{tabular}{|c|c|c|c|c|}
\hline rear & 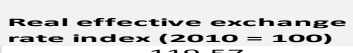 & $\begin{array}{l}\text { Exports of gooudsand } \\
\text { services }(\% \text { of }\end{array}$ & 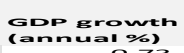 & $\begin{array}{l}\text { Malation, } \\
\text { camsimat prices }\end{array}$ \\
\hline $\begin{array}{l}1990 \\
1991 \\
1992\end{array}$ & $\begin{array}{l}119.57 \\
123.07 \\
120.21 \\
0\end{array}$ & $\begin{array}{l}23.97 \\
22.35 \\
22.65\end{array}$ & $\begin{array}{l}0.73 \\
-1.10 \\
0.40\end{array}$ & $\begin{array}{r}8.06 \\
3.46 \\
4.59\end{array}$ \\
\hline $\begin{array}{l}1993 \\
1904\end{array}$ & $\begin{array}{l}108.61 \\
108 \\
100\end{array}$ & $\begin{array}{l}24.56 \\
25.79\end{array}$ & $\begin{array}{l}2.49 \\
\text { 2. } 85 \\
\text { 3. }\end{array}$ & $\begin{array}{l}2.50 \\
2.22\end{array}$ \\
\hline 1995 & $\begin{array}{l}104.97 \\
106.45 \\
1035\end{array}$ & $\begin{array}{l}25.55 \\
25.15 \\
25.156\end{array}$ & $\begin{array}{l}\frac{2.53}{2.49} \\
2.49\end{array}$ & $\begin{array}{l}50 \\
55\end{array}$ \\
\hline 19989 & $\begin{array}{l}129.25 \\
129.11\end{array}$ & 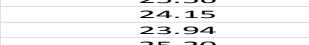 & $\begin{array}{l}\text { 3. } \\
\text { 3. } 30 \\
\text { 3. } 30\end{array}$ & $\begin{array}{l}82 \\
75 \\
75\end{array}$ \\
\hline 2003 & $\begin{array}{l}137.26 \\
128.16\end{array}$ & $\begin{array}{l}25.19 \\
24.23\end{array}$ & $\begin{array}{l}3.51 \\
2.13 \\
2.18\end{array}$ & $\begin{array}{l}1.53 \\
52\end{array}$ \\
\hline & $\begin{array}{l}12293 \\
127.97 \\
1253\end{array}$ & $\begin{array}{l}2 \\
23: 93 \\
25: 06\end{array}$ & $\begin{array}{l}\frac{3}{3} \cdot 32 \\
2.29 \\
2.96\end{array}$ & \\
\hline 2000 & $\begin{array}{l}126.18 \\
128 \\
111.27\end{array}$ & $\begin{array}{l}27.28 \\
25: 36 \\
27: 05\end{array}$ & $\begin{array}{l}2: 69 \\
2.36 \\
-0.27\end{array}$ & 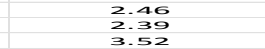 \\
\hline & & $\begin{array}{l}26.40 \\
28.25\end{array}$ & & \\
\hline & $\begin{array}{l}98.83 \\
1003.40\end{array}$ & $\begin{array}{l}30.71 \\
29.99 \\
29.87\end{array}$ & $\begin{array}{l}1.28 \\
1.23 \\
1.29\end{array}$ & $\begin{array}{l}85 \\
53 \\
50\end{array}$ \\
\hline $\begin{array}{l}2013 \\
2015 \\
2013\end{array}$ & $\begin{array}{l}102.70 \\
113.76 \\
1130\end{array}$ & $\begin{array}{l}2 \\
28.20 \\
28.26 \\
37.26\end{array}$ & $\begin{array}{l}\frac{3}{2} \cdot 86 \\
2.36 \\
2.35\end{array}$ & 37 \\
\hline $\begin{array}{l}2016 \\
2013 \\
2013\end{array} \mid$ & $\begin{array}{l}102.38 \\
97.08 \\
98.85 \\
98.85\end{array}$ & 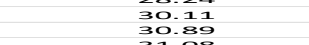 & $\begin{array}{l}1.74 \\
1.25 \\
1.25\end{array}$ & \\
\hline 20019 & $\begin{array}{l}98.42 \\
98.62\end{array}$ & $\begin{array}{l}31.08 \\
27.37\end{array}$ & 19.79 & \\
\hline
\end{tabular}

